\title{
THE EFFECT OF TAX SOCIALIZATION AND TAX RATES TO RESTAURANT TAXPAYABLE COMPLIANCE IN THE CITY OF SUKABUMI
}

\author{
Irsan Permana ${ }^{1}$, Tri Endar Susianto ${ }^{2}$ * \\ ${ }^{1,2}$ Accounting Department - STIE Pasim Sukabumi, Indonesia. \\ *Corresponding Author, email: abu.irsyad32@gmail.com
}

Received: 11.12.2020

Revised: 23.12 .2020

Accepted: 29.12.2020

ABSTRACT

This study aims to determine the tax socialization, tax rates, tax compliance, the influence of tax socialization on tax compliance, the influence of tax rates on tax compliance, and the effect of tax socialization and tax rates on restaurant taxpayer compliance in Sukabumi City.

The research method uses quantitative methods with descriptive-associative methods. The unit of analysis used is restaurants in Sukabumi City, with the population used are all restaurants in Sukabumi City, and the total sample size of 70 respondents. Data collection techniques in the form of a questionnaire containing 19 indicator statements and determined by the simple random sampling method. Analysis of the data used is the instrument test, classic assumption test, descriptive analysis, multiple correlation analysis, coefficient of determination analysis, multiple linear regression analysis, and t test (partial test) and $F$ test (simultaneous test).

The results of this study indicate that; 1) tax socialization based on restaurant respondents' responses shows that on the whole the overall response was agreed with the tax socialization conducted towards restaurants in Sukabumi City. 2) tax rates based on respondents' responses indicate that on average the overall response was neutral with the imposition of tax rates on restaurants in the City of Sukabumi. 3) taxpayer compliance based on respondents' responses shows that on average the overall respondent agreed to the compliance of restaurant taxpayers in Sukabumi City, in the sense that respondents were compliant with the existence of taxpayers to their respective restaurants. 4) tax socialization has a positive and significant effect on restaurant taxpayer compliance in Sukabumi City. 5) tax rates have a positive and significant effect on restaurant taxpayer compliance in Sukabumi City. 6) tax socialization and tax rates have a positive and significant effect on restaurant taxpayer compliance in Sukabumi City.

Keywords: Socialization of Tax, Tax Rates, Tax Compliance, Restaurant

\section{INTRODUCTION}

Today most countries in the world have tax systems to finance their government expenditures. The tax in Indonesia is no exception, which is one of the state revenues used to carry out development for all Indonesian people. Taxes are collected from Indonesian citizens and is one of the obligations that the collection can be forced on. Taxes have a very important role because they are the main source of state revenue to finance state development, guarantee 
the welfare of its people, so that the government in this case continues to strive to increase state revenue from the taxation sector. Taxes are compulsory contributions to the state that are owed by individuals or entities that are compelling based on law,

Constrained from this aspect, Restaurant Tax is one of the Regency / City Taxes which greatly affects the economy in the State of Indonesia which is part of local taxes. Every service provided by the restaurant with payment is levied under the name Restaurant Tax. Restaurant is a food and / or beverage provider facility for free, which includes restaurants, cafeterias, canteens, stalls, bars, and the like including catering services where the restaurant tax rate is set at $10 \%$. In Sukabumi City itself, the restaurant tax is targeted to reach IDR 5.8 billion, in which the tax from the restaurant sector can encourage additional sources of PAD. This is because the area of Sukabumi City is one of the transit places visited by the community, including residents outside the city of Sukabumi (jabar.pojoksatu.id).

The following is an illustration of the development of the number of restaurants in the city of Sukabumi which is followed by data on the development of restaurant taxpayers that have been registered with the Regional Financial Management Agency of Sukabumi City, shown in the following table:

\section{Table 1}

Number of Restaurants and Restaurant Taxpayers in Sukabumi City

\begin{tabular}{cccc}
\hline Year & $\begin{array}{c}\text { Restaurants in } \\
\text { Sukabumi City }\end{array}$ & $\begin{array}{c}\text { Restaurants that are registered } \\
\text { taxpayers in Sukabumi City }\end{array}$ & Percentage \\
\hline 2017 & 75 & 54 & $75 \%$ \\
2018 & 216 & 120 & $55.5 \%$ \\
2019 & 232 & 136 & $58.6 \%$ \\
\hline
\end{tabular}

Source: (Sukabumi City Regional Financial Management Agency, 2019).

Based on the information in the table above, it can be seen that the number of restaurants in Sukabumi City in 2017 is 75 restaurants, of which 54 restaurants are registered, or only $75 \%$ of the total number of restaurants. In 2018 the number of restaurants in Sukabumi City experienced a very significant development where the number of restaurants rose to 216 restaurants, and of which 120 restaurants were registered with the taxpayer, ironically this number was only $55.5 \%$ of the total existing restaurants. and clearly decreased from the previous year when viewed from compliance. In 2019 (current update), the number of restaurants in Sukabumi City is 232 restaurants, with a total of 136 restaurants registered with the taxpayer, or the number is only $58.6 \%$ of the total existing restaurants. In this case it can be said that the increase in existing restaurants is not proportional to the increase in the number of restaurant taxpayers who are registered or comply with taxpayers. In Sukabumi City itself, the 
regional tax target for 2019 according to the Head of the Sukabumi City BPKD and Non-Tax Collection is 2.1 billion, one of which is expected from the restaurant tax (portal.sukabumikota.go.id).

This research is a kind of research from Julianto's [1] research. This study builds on previous research but with several differences. This study is focused only on discussing several objects, namely tax socialization, tax rates and taxpayer compliance, and the subject used is different, if in previous studies using MSMEs in Semarang City as subjects, this research is more focused on restaurants as subjects in the city of Sukabumi.

\section{LITERATURE REVIEW}

\section{Tax Accounting}

According to Mardiasmo [2] the definition of tax according to law Number 16 of 2009 concerning the fourth amendment to law Number 6 of 1983 concerning General Provisions and Tax Procedures in article 1 Paragraph 1 reads that tax is the taxpayer's contribution to the indebted State. by private persons or bodies of a coercive nature based on law, without receiving direct compensation and being used for state needs for the greatest welfare of the people.

From these definitions, it can be concluded that taxes have elements of contributions from the people to the state, only the state is entitled to collect taxes. Based on law, taxes are collected based on or with the force of law and its implementing regulations. Without reciprocal services or counterparts from the country that can be directly appointed, in the payment of taxes it cannot be shown that there are individual contradictions by the government. Used to finance state households, namely expenses that are beneficial to the wider community [2].

Taxes have a very important role in the life of the state, especially as a source of financing and state development. According to Mardiasmo [2] taxes have two functions, namely:

1. Budget Function (Budgetair); tax serves as a source of funds for the government to finance its expenses.

2. Function Set (Regularend); tax functions as a tool to regulate or implement government policies in the social and economic fields.

\section{Tax Socialization}

Tax extension activities have an important role and contribution in socializing taxes to all taxpayers. Various media are expected to be able to arouse public awareness to comply with taxes and bring moral messages on the importance of taxes for the State. Various media are 
expected to be able to raise awareness of taxpayers and increase taxpayer compliance of both corporate and individual taxpayers in order to increase the amount of state revenue.

Ritcher Jr. [3] socialization is the process of a person acquiring knowledge, skills and attitudes in order to function as an adult and at the same time as an active actor in a certain position or role in society. Soekanto [4] states that socialization is the process of building or instilling group values in a person, in this case the importance of a tax. From some of the opinions above, it can be concluded that some of the main notions of socialization are as follows:

1). Socialization is a process that takes place throughout human life.

2). In socialization there is mutual influence between individuals and all the human potentials of society and culture.

3). Through the process of socialization, individuals absorb knowledge, beliefs, values, norms, attitudes and skills from the culture of their community.

4). The result of socialization is the development of a person's personality into a unique person, while the culture of the community is also maintained and developed through the process of socialization.

After knowing the meaning of socialization and tax above, it can be explained that the meaning of tax socialization is an effort of the Directorate General of Taxes to provide understanding, information and guidance to the public in general and taxpayers in particular regarding everything related to taxation legislation. With the tax socialization carried out by the Directorate General of Taxes, it is hoped that effective participation of the public and taxpayers will be created in fulfilling their rights and obligations so as to allow an awareness of taxation to be maintained.

Soekanto [4] adjustments in socialization occur gradually in accordance with the development of increased knowledge and individual acceptance of the values and norms that exist in the community where society is located.

A person will experience a continuous socialization process as long as the individual lives from children to adults. This includes the socialization of taxation, sooner or later taxation must be known and understood by all levels of society in studying taxation.

The aspects that will be obtained from the delivery of tax information by the government will greatly affect the awareness of taxpayers in paying taxes, [4], among others: 
1) Time; In socializing taxes, the Directorate General of Taxes can use time at every available opportunity, either by visiting each home or place of business, or when the taxpayer himself comes to the local tax office.

2) Media used; media information about taxes comes from mass media, but outdoor media is also a source of tax information that is noticed by the public, so information media should be more widely used in tax dissemination, namely: Television, Newspapers, Banners, Flyer media (banners and posters), Radio, Media Billboards / mini billboards and internet media.

3) Form of socialization; the form of socialization in the form of delivery of socialization material to the public should emphasize more on tax benefits, NPWP benefits and tax services in each unit. Socialization is carried out to the community through seminars, discussions, and outreach.

4) Information submitted; the quality of the information conveyed should use the simplest language possible and not technical in nature, so that the information can be well received. Sources of information that are considered informative and required in order are: Call Center, Extension, Internet, Tax Officers, Television, Advertising.

5) The purpose and benefits of socialization; DGT's programs are related to counseling activities, tax seminars and tax debates through the tax goes to campus event aimed at generating an understanding of taxes for students and the general public.

\section{Tax rates}

The tax rate is the basis for the imposition of taxes on the tax object which is the responsibility. Tax rates in Indonesia are divided into fixed rates, proportional rates, degressive rates, and progressive rates [5]. The tax rate is the percentage (\%) or amount (rupiah) of tax that must be paid by the taxpayer in accordance with the tax base or tax object [6]. The government has an important role in determining the tariff setting policy [7]. Government Regulation No. 46 of 2013, the regulation explains that individual taxpayers and corporate taxpayers with income not included from services related to free work. Based on those definition, it can be concluded that the tax rate is the percentage used to calculate the tax that must be paid by someone based on justice and the provisions of the applicable law.

According to Sormin, et al. [5] there are types of taxes in Indonesia, including the following:

1. Fixed Rates; Fixed rate means the amount of tax payable is calculated by applying a constant tax rate regardless of the tax base (DPP). 
2. Proportional Rates; What is meant by proportional rate is a certain rate in the form of a constant percentage applied to whatever the DPP is so that the payable tax increases when the DPP increases and vice versa, the tax payable is always proportional or proportional.

3. Degression Rates; degression tariff is the percentage of tax collection rate which uses a decreasing percentage if the amount on which the tax is based increases.

4. Progressive Fares; progressive tariff is a certain tariff in the form of an increasing percentage which is applied when the DPP increases.

\section{Restaurant Tax Rates}

The restaurant tax rate regulated by Government Regulation Number 46 of 2013 is a simplification tax rate in the form of a $1 \%$ final tax rate, while the previous rate regulated in Law No. 36 of 2008 (PPh Law) article $31 \mathrm{E}$ which states that domestic corporate taxpayers with a gross circulation of up to $\mathrm{Rp}$. 50,000,000,000 receive facilities in the form of reduced rates of $50 \%$ of the general rate as regulated in article 17 paragraph (2) of the Income Tax Law subject to Taxable income from the gross revenue share of up to Rp. 4.8 billion.

Some people think that the tax rate is higher than the previous tax rate, because the current tax rate is $1 \%$ of turnover regardless of whether it experiences a loss or profit and is not reduced by non-taxable income [8].

\section{Taxpayer Compliance}

According to Sormin et al. [5] as in Article 1 point 2 (two) of Law no. 28/2007 The Taxation Law Kitap (KUP) states that taxpayers are individuals or entities, including tax payments, tax cutters, and tax collectors, who have tax rights and obligations in accordance with the provisions of taxation legislation. From this definition it can be concluded that the taxpayer is an individual or entity or can be called a tax subject. Income tax (PPh) can only be imposed if the requirements of the tax subject and tax object have been met. The definition or definition of the requirements of this taxpayer is as follows:

1. Subjective Requirements; requirements in accordance with the provisions regarding the tax subject in the 1984 income tax law and the latest amendment to the Income Tax Law No. 36 of 2008 .

2. Objective Requirements; requirements for tax subjects who receive or earn income or are required to deduct collection in accordance with the provisions of the Income Tax Law No. 36 of 2008. 
According to Sormin et al. [5] as explained in article 2 of the KUP Law No. 2 of 2007 states that every taxpayer has fulfilled subjective and objective requirements in accordance with the provisions of taxation laws and is obliged to register himself at the office of the Directorate General of Taxes whose working area includes the residence or domicile of the Taxpayer and is given a Taxpayer Identification Number (NPWP). ).

Taxpayer Compliance is the act of a Taxpayer in fulfilling its tax obligations. Nurmantu [9] defines tax compliance as a condition for the fulfillment of all tax obligations and tax rights. Taxpayers are said to be compliant (tax compliance) if the reported income is appropriate, the Tax Return (SPT) is reported and the amount of tax owed is paid on time [10]. Nurmantu [9] explains that there are two taxpayers' compliance, namely formal compliance and material compliance.

Formal compliance is a condition in which the taxpayer fulfills its tax obligations formally based on the provisions in law. Taxpayer compliance in paying taxes formally is seen from the aspect of Taxpayer awareness to register, timeliness in paying taxes, timeliness in submitting SPT, and reporting Taxpayers to make payments on time. Definition of Material Compliance means that all material tax provisions can be fulfilled substantive, meaning that they are based on tax law. Based on the Decree of the Minister of Finance Number 544 / KMK.04 / 2000, taxpayers are included in the compliant category if they meet the following criteria:

1. Notification Letter (SPT) is submitted in a timely manner, which applies to all types of taxes within the last 2 years.

2. Taxpayers have never received a tax crime in the last 10 years.

3. Taxpayers never have tax arrears for all types of taxes, but on condition that they get permission to postpone taxes or installments of taxes that must be paid.

4. The taxpayer's financial statements within the last two years have been audited by a public accountant with unqualified income or taxable profit and loss on income with exceptions not affected, provided that the reconciliation of taxable and commercial income must be presented with a long form report.

5. Based on article 28 of the KUP Law, taxpayers have been keeping track of the last two years during the tax period.

According to the Minister of Finance Regulation No. 192 / PMK.03 / 2007 the criteria for compliant taxpayers are: First, on time submission of Tax Returns (SPT) includes: submission of Annual Notifications on time in the last 3 (three) years, submission of Periodic Tax Returns 
that are late in the last year for the Tax Period from January to November, no more than 3 tax periods for each type of tax and not consecutive, the overdue SPT as referred to in letter b has been submitted no later than the deadline for submitting the Periodic SPT for the next tax period. Second, do not have tax arrears for all types of taxes, unless you have obtained permission to pay installments or postpone tax payments, covering the situation on December 31 of the year before the determination.

\section{RESEARCH METHODS}

\section{Research Design and Procedures}

Quantitative research methods will be used for this type of research, using descriptiveassociative methods. According to Sugiyono [11] descriptive research is research conducted to determine the value of the independent variable, either one or more (independent) variables without making comparisons, or connecting with other variables. Then Sugiyono [11] told that associative research is research that aims to determine the effect or relationship between two or more variables.

The procedure in this study includes quantitative research procedures from starting to determine the focus of the research to drawing the conclusions described in the following figure.

\section{Population and Sample}

According to Sugiyono [11] population is a generalization area consisting of objects / subjects that have certain qualities and characteristics that are determined by researchers to study and then draw conclusions. In this study, the population selected was all restaurants in Sukabumi City (update on March 2019), totaling 232 restaurants [12].

As for determining the sample size of this study using the Slovin formula, because in sampling, the number must be representative so that the results of the study can be generalized. Slovin formula for determining the sample is as follows:

$$
n=\frac{N}{1+\left(N \cdot e^{2}\right)}
$$

Information:

a) $n=$ number of samples

b) $N=$ population size

c) $e=$ error tolerance

By using this method for a population of 232 and a fault tolerance limit of $10 \%$, the sample size is: 


$$
n=\frac{N}{1+\left(N \cdot e^{2}\right)}=\frac{232}{1+\left(232 \cdot(0,1)^{2}\right)}=69,8 \approx 70
$$

Based on the above calculations, the sample who became the respondents in this study was adjusted to be 70 restaurants or $30.1 \%$ of all restaurants in Sukabumi City. This is done to facilitate data processing and for better test results.

In this study, the sample was taken using probability sampling with the type of simple random sampling, where the researcher provided equal opportunities for each member of the population (restaurant), whether registered with the taxpayer or not registered with the taxpayer, to be selected as a random sample.

\section{Data collection technique}

Sources of data in this study using primary sources. Primary sources are data sources that directly provide data to data collectors [11]. And data collection techniques in this study using a questionnaire technique in the form of a questionnaire. According to Sugiyono [11] a questionnaire is a data collection technique that is done by giving a set of questions or written statements to respondents to answer. By distributing questionnaires to measure respondents' attitudes / perceptions using the measurement scale used is the Likert scale.

\section{Operationalization of Variables}

There are two variables in this study including the independent variable and the dependent variable as follows.

1. Independent Variable (X); The independent variable in this study is the Socialization of Taxes and Tax Rates.

2. Dependent Variable (Y); The dependent variable in this study is Taxpayer Compliance.

\section{Statistical Hypothesis}

The hypothesis to be tested in this study is related to the presence or absence of influence between the Tax Socialization variable (X1) and the Tax Rate (X2) on the Taxpayer Compliance variable (Y), then the statistical hypothesis is formulated as follows:

1. Ho1 = Tax Socialization has an effect on Restaurant Taxpayer Compliance in Sukabumi City, and Ha1 = Tax Socialization has no effect on Restaurant Taxpayer Compliance in Sukabumi City.

2. Ho2 $=$ Tax rate affects Restaurant Taxpayer Compliance in Sukabumi City, and Ha2 $=$ Tax rate has no effect on Restaurant Taxpayer Compliance in Sukabumi City. 
3. Ho3 = Socialization of Taxes and Tax Rates have an effect on Restaurant Taxpayer Compliance in Sukabumi City, and Ha3 = Socialization of Taxes and Tax Rates have no effect on Restaurant Taxpayer Compliance in Sukabumi City.

\section{Data analysis}

\section{Research Instrument Test}

In this study, the test instruments used included validity and reliability tests. According to Ghozali (2016: 120) the validity test is used to measure whether a questionnaire is valid or not. A questionnaire is said to be valid if the questions on the questionnaire are able to reveal something that will be measured by the questionnaire. This validity test was carried out using the Pearson Correlation formula (Product Moment Correlation).

The basis for making a decision on an item or item is valid or invalid, it can be seen by correlating the item score with the total score, it can be at a significance level of $10 \%$ provided that $r_{\text {hitung }}>r_{\text {tabel }}$ It can be concluded that the instrument items are valid, otherwise if

$r_{\text {hitung }}<r_{\text {tabel }}$ it can be concluded that the instrument item is invalid so it must be repaired or discarded.

Reliability test is a tool for measuring a questionnaire which is an indicator of the variable. A questionnaire is said to be reliable or reliable if a person's answer to a question is consistent or stable over time [13].

According to Ghozali [13], a construct or variable is said to be reliable or reliable in each questionnaire indicator if it gives a Cronbach Alpha value> 0.60 .

The basis for making a decision on an item or item is declared reliable or unreliable according to Ghozali [13] is if:

- Result $\alpha>0,6=$ reliable

- Result $\alpha<0,6=$ not reliable

\section{Classic assumption test}

The data analysis stage used was the classical assumption test which included normality test, multicollinearity test, heteroscedasticity test, and auto correlation test.

Normality test to assess whether the residual value is normally distributed or not. A good regression model is to have residual values that are normally distributed. So the normality test is not carried out on each variable but on the residual value. There are often multiple errors, namely that the normality test is carried out on each variable. This is not prohibited but the 
regression model requires normality in its residual values. Not on each research variable (Ansofino, 2016: 95).

To test the normality of the data in this study, graph analysis was used, namely by analyzing the normal probability plot graph. Data can be said to be normal if the data or points are scattered around the diagonal line and the distribution follows the diagonal line. The data will be normal if the significance is $<\alpha=0.05$.

The multicollinearity test is to see whether or not there is a high correlation between the independent variables in a multiple linear regression model. If there is high correlation between the independent variables, the relationship between the independent variables and the dependent variable will be disturbed [14].

A good regression model should not have correlation between the independent variables. If the independent variables are correlated, these variables are not orthogonal. To detect multicolonierity in the regression model, the correlation coefficient between independent variables is $\leq 0.60$ and multicolonierity can also be seen from the tolerance value and variance inflation factor (VIF). Tolerance measures other independent variability.

The heteroscedasticity test is to see if there is an inequality of variance from one residual to one observation to another. Regression models that meet the requirements are where there is a similarity in variance from the residuals of one observation to another, which is fixed or called homoscedasticity [14].

A good regression model is a regression that is free from heteroscedasticity. Testing is done by looking at the plot image between the predicted values of the independent variables and their residuals. If the graph does not have a certain regular pattern and the data is randomly distributed above and below the number 0 on the $\mathrm{Y}$ axis, then no heteroscedasticity is identified.

The autocoleration test conducted in this study aims to test whether in a linear regression model there is a correlation between the confounding error in period $t$ and the error in period $t$ 1 (previous). The method that can be used to detect the presence or absence of authentication is the Durbin Waston test (DW test). The DW test is used for level one correlation and requires a constant in the regression model and no lag variable between the independent variables.

\section{Descriptive Analysis}

Descriptive statistical research is used as an analytical technique with the aim of explaining or providing an overview of the number of returned questionnaires and comparisons with the questionnaires sent by presenting a table containing the maximum, minimum, mean, 
and standard deviation values obtained from the respondents' answers received. In this study, the use of descriptive statistical tests is used to describe an overview of the object and subject of the study, namely the characteristics of the respondent and the results of the respondent's response.

\section{Multiple Correlation Analysis}

Multiple correlation analysis is intended to see the relationship between three or more variables (two independent variables and one dependent variable). Multiple correlation deals with the intercorrelation of the independent variables as well as their correlation with the dependent variable.

The magnitude of correlation -1 is perfectly negative, that is, there is a relationship between two or more variables but the direction is reversed, +1 is the perfect positive correlation coefficient (very strong), that is, there is a relationship between two or more variables, while the correlation coefficient of 0 is considered to have no relationship. between two or more variables tested so that it can be said that there is no relationship at all.

\section{Analysis of the coefficient of determination}

The coefficient of determination is used to determine how far an independent variable determines the change in the value of the dependent variable. The value of the coefficient of determination lies between zero and one. Small $\mathrm{R}^{2}$ value means that the ability of the independent variables to explain the dependent variables is very limited. On the other hand, if the value is close to 1 , it means that the independent variables provide almost all the information needed to predict the dependent variables.

\section{Multiple Linear Regression Analysis}

According to Ghozali [13] multiple linear regression analysis is a linear regression to analyze the magnitude of the relationship and the influence of independent variables with more than two numbers. The multiple linear regression model equation in this study is as follows:

$$
Y=a+b_{1} X_{1}+b_{2} X_{2}
$$

Information:

- $\quad Y=$ Dependent variable (Taxpayer Compliance)

- $X_{1}=$ Independent variable (Tax Socialization)

- $X_{2}=$ Independent variable (Tax Rate)

- $b_{1}=$ Regression coefficient (Liquidity) 
- $\quad b_{2}=$ Regression coefficient (solvency)

- $a=$ Constant

\section{Partial Regression Test (t test)}

The $t$ test was conducted to determine the size of each independent variable individually on the dependent variable. To determine whether there is an effect of each independent variable individually on the dependent variable, it is done by comparing the p-value in the Sig column. each independent variable with a significant level used 0.05. If the p-value> degree of confidence $(0.05)$ then $\mathrm{H} 1, \mathrm{H} 2$, and $\mathrm{H} 3$ are rejected. This means that there is no significant effect of the independent variables individually on the dependent variable, and vice versa. Likewise to compare $\mathrm{t}$ count with $\mathrm{t}$ table. If $\mathrm{t}$ count $>\mathrm{t}$ table then $\mathrm{H} 1, \mathrm{H} 2$, and $\mathrm{H} 3$ are accepted. This means that there is a significant effect of the independent variables individually on the dependent variable, and vice versa.

\section{Simultaneous Regression Test (Test F)}

The $\mathrm{F}$ test is performed to determine the effect of the independent variables simultaneously (together) on the dependent variable. To find out which independent variables simultaneously influence the dependent variable, it is done by comparing the p-value in the Sig column. with a significance level used of 0.05 . If the $p$-value> degree of confidence $(0.05)$ then $\mathrm{H} 1, \mathrm{H} 2$ and $\mathrm{H} 3$ are rejected. This means that the independent variables together do not significantly affect the dependent variable, and vice versa. Likewise for F count and F table. If F count> F table then $\mathrm{H} 1, \mathrm{H} 2$, and $\mathrm{H} 3$ are accepted. This means that the independent variables together significantly influence the dependent variable, and vice versa.

\section{RESULTS AND DISCUSSION}

\section{Respondent Description}

The characteristics of the respondent's description used in this study refer to the sample used, namely restaurants in the city of Sukabumi. Characteristics of respondents, namely restaurants in the city of Sukabumi, in this case are described by the length of the business and the status of the taxpayer. 
Table 2

\section{Long Established Business}

\begin{tabular}{llr|r|r|r} 
& Frequency & Percent & Valid Percent & Cumulative Percent \\
\hline Valid & $<5$ years & 28 & 40.0 & 40.0 & 40.0 \\
\cline { 2 - 6 } & $>10$ Years & 12 & 17.1 & 17.1 & 57.1 \\
\cline { 2 - 6 } $5-10$ Years & 30 & 42.9 & 42.9 & 100.0 \\
\hline Total & 70 & 100.0 & 100.0 & \\
\hline
\end{tabular}

Source: (Taken from the Appendix, 2019)

Table 3

\section{Taxpayer Status}

\begin{tabular}{ll|r|r|r|r} 
& & & Valid & Cumulative \\
& & Frequency & Percent & Percent & \multicolumn{1}{c}{ Percent } \\
\hline Valid & Registered with the Taxpayer & 50 & 71.4 & 71.4 & 71.4 \\
\cline { 2 - 6 } & Not Registered with Taxpayers & 20 & 28.6 & 28.6 & 100.0 \\
\cline { 2 - 6 } & Total & 70 & 100.0 & 100.0 & \\
\hline
\end{tabular}

Source: (Taken from the Appendix, 2019)

Judging from the results in Table 2 regarding the long established business, the authors categorize it into 3 categories and in this case there are 28 restaurants with a long standing of less than 5 years ( $<5$ years) or about $40 \%$ of the restaurants sampled, then there are 30 restaurants with a length of time. established about 5 to 10 years or about $42.9 \%$ of the total restaurants sampled, and finally there were 12 restaurants with a long standing of more than 10 years (> 10 years) or around $17.1 \%$ of the total restaurants sampled. Thus it can be concluded that it is not surprising that in recent times there has been an increase in the number of restaurants due to innovations in the millennial era because Sukabumi City is very much dominated by new or recently established restaurants.

Meanwhile, if seen from the results in Table 3 regarding the status in Taxation, the authors categorize it into 2 categories and in this case there are 50 restaurants that have been registered with the taxpayer or about $71.4 \%$ of the total restaurants sampled, as well as 20 restaurants that have not been registered with taxpayers or about $28.6 \%$ of the total sample restaurants. Thus it can be concluded that most restaurants in Sukabumi are tax compliant where they already have a business NPWP or are registered with the taxpayer.

\section{Research Instrument Test}

Reliability is a tool for measuring an instrument which is an indicator of a variable. An instrument is said to be reliable or reliable if someone's answer to a question is consistent or stable over time. The results of the instrument reliability test in this study are shown in the 
following table. Model testing was carried out using the help of the IBM SPSS Statitics 24.0 for Windows program with the following analysis results.

\section{Table 4}

\section{Reliability Test Results}

\begin{tabular}{l|r|r} 
& \multicolumn{2}{c}{ Reliability Statistics } \\
& Cronbach's Alpha & \multicolumn{1}{c}{ N of Items } \\
\hline Tax Socialization (X1) & $\mathbf{. 6 7 7}$ & 6 \\
\hline Tax Rate (X2) & $\mathbf{. 6 6 1}$ & 4 \\
\hline Taxpayer Compliance (Y) & $\mathbf{. 7 5 8}$ & 9 \\
\hline
\end{tabular}

Source: (Taken from the Appendix, 2019)

Based on the output results in Table 4, it can be seen that the average value of Cronbach's Alpha of all tax socialization variables $(X 1)=0.677$; tax rate $(X 2)=0.661$; and taxpayer compliance $(Y)=0.758$. This is greater than 0.600 in accordance with the requirements of the reliability test decision, meaning that the statement items of the Tax Socialization variable (X1), tax rates (X2), and Taxpayer Compliance (Y) in this study are reliable.

Validity means the extent to which the accuracy and accuracy of a measuring instrument performs its function. The higher the validity of a measuring instrument, the more precise the measuring device will hit the target. In this study, the decision making requirements for the validity test used a significance level of $\alpha=5 \%, \mathrm{~N}=70$, valuertabel $=0.1982$,

Based on the results of the output on model testing carried out using the IBM SPSS Statistics 24.0 for Windows program, it can be seen that the value $r x y$ of the tax socialization variable statement items $(\mathrm{X} 1)$ are X1.1 $=0.816, \mathrm{X} 1.2=0.428, \mathrm{X} 1.3=0.439, \mathrm{X} 1.4=0.770$, $\mathrm{X} 1.5=0.601$, and X1.6 $=0.218$ which This indicates that the overall product moment correlation value of the tax socialization variable (X1) is greater than rtabel (0.1982) in accordance with the requirements for decision making of the validity test so it can be concluded that all statement items in the Tax Socialization research instrument (X1) are declared valid and pass the validity test.

Based on the results of the IBM SPSS Statistics 24.0 for Windows output, it can be seen that the value $r x y$ of the tax rate variable statement items (X2) are respectively X2.1 $=0.498$, $\mathrm{X} 2.2=0.749, \mathrm{X} 2.3=0.769$, and X2.4 $=0.591$ which indicates the overall product moment correlation value of the tax rate variable (X2) greater than rtabel (0.1982) in accordance with the requirements for decision making of the validity test, so it can be concluded that all statement items in the Tax Rate (X2) research instrument are declared valid and pass the validity test. 
The output result of the IBM SPSS Statistics 24.0 for Windows program can be seen that the value $r x y$ of the taxpayer compliance variable statement items $(\mathrm{Y})$ are $\mathrm{Y} 1=0.660, \mathrm{Y} 2=$ $0.588, \mathrm{Y} 3=0.246, \mathrm{Y} 4=0.608, \mathrm{Y} 5=0.759, \mathrm{Y} 6=0.823, \mathrm{Y} 7=0.823, \mathrm{Y} 8=0.472$, and $\mathrm{Y} 9=$ 0.610 which indicates that the overall product moment correlation value of the taxpayer compliance variable (Y) is greater than rtabel (0.1982) in accordance with the requirements for making the validity test decision, so it can be concluded that all statement items in the Taxpayer Compliance research instrument $(\mathrm{Y})$ are declared valid and pass the validity test.

\section{Classical Assumption Test Results}

Data can be said to be normal if the data or points are spread around the diagonal line and the distribution follows the diagonal line. In this study, to test the normality of the data used, namely by analyzing the normal probability plot graph as follows:

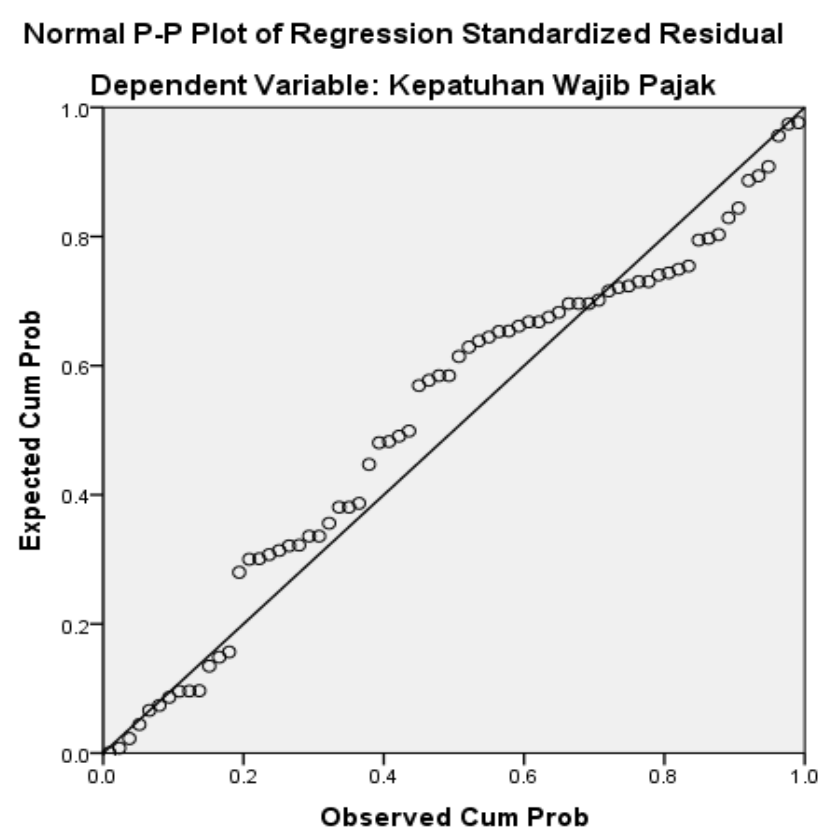

Figure 1

\section{Normal Probability Plot Normality Test Results}

(Source: Taken from the Appendix, 2019)

From the normal p-plot graph above, it can be seen that the data distribution is centered on the average value and the media or p-plot value is located on the diagonal line, so it can be said that the data of this study has a normal distribution and distribution. With normal data in this study, this research can be continued.

The multicollinearity test is to see whether or not there is a high correlation between the independent variables in a multiple linear regression model. If there is high correlation between 
the independent variables, the relationship between the independent variables and the dependent variable will be disturbed (Ansofino, 2016: 95).

Table 5

\section{Multicollinearity Test Results}

\begin{tabular}{|c|c|c|c|c|c|c|c|}
\hline \multirow[b]{3}{*}{ Model } & \multicolumn{5}{|c|}{ Coefficientsa } & & \\
\hline & \multicolumn{2}{|c|}{$\begin{array}{l}\text { Unstandardized } \\
\text { Coefficients }\end{array}$} & \multirow{2}{*}{$\begin{array}{c}\text { Standardized } \\
\text { Coefficients } \\
\text { Beta }\end{array}$} & \multirow[b]{2}{*}{$\mathrm{T}$} & \multirow[b]{2}{*}{ Sig. } & \multicolumn{2}{|c|}{$\begin{array}{c}\text { Collinearity } \\
\text { Statistics }\end{array}$} \\
\hline & $\mathrm{B}$ & Std. Error & & & & Tolerance & VIF \\
\hline 1 (Constant) & 5,559 & 3,186 & & 1,745 & .086 & & \\
\hline $\begin{array}{l}\text { Tax } \\
\text { Socializatio } \\
\mathrm{n}\end{array}$ & .921 & .169 & .538 & 5,465 & .000 & .619 & 1,616 \\
\hline Tax rates & .614 & .191 & .316 & 3,216 & .002 & .619 & 1,616 \\
\hline
\end{tabular}

a. Dependent Variable: Taxpayer Compliance

Source: (Taken from the Appendix, 2019)

Based on table 5 above, it is known that there are no independent variables that have a VIF (variance inflation factor) value greater than 10 and no independent variables have a Tolerance value of less than 0.10 so that it can be concluded that there is no multicolonierity between the independent variables in the regression model. .

The heteroscedasticity test is to see whether there is an inequality of variance from one residual to another (Ansofino, 2016: 96).

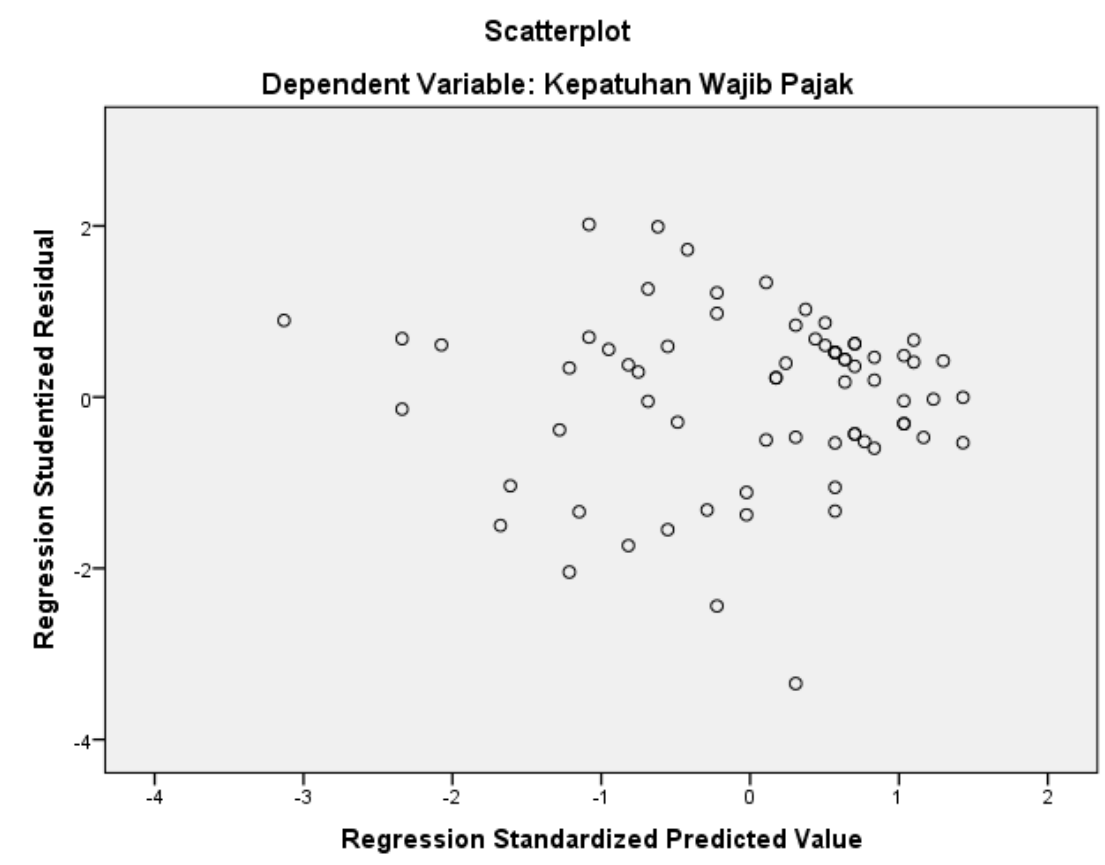

Figure 2

Scatterplot Graph Heteroscedasticity Test Results

(Source: Taken from the Appendix, 2019) 
The results of the heteroscedasticity test using a scatterplot graph can be seen that the data is spread above and below the 0 (zero) number on the $\mathrm{Y}$ axis and there is no clear pattern in the distribution of the data. This means that there is no heteroscedasticity in the regression equation model, so that the regression model is appropriate to be used to predict taxpayer compliance (Y) based on the independent variables that influence it, namely tax socialization (X1) and tax rates $(\mathrm{X} 2)$.

The autocoleration test conducted in this study aims to test whether in a linear regression model there is a correlation between the confounding error in period $t$ and the error in period $t$ 1 (previous).

The Durbin Watson value from the SPSS results is 1.730 , the comparison uses a significance value of $5 \%$, the number of samples is 70 (n), and the number of independent variables $2(\mathrm{k}=2)$, then the Durbin Watson table will get a du value of 1.6715. Because the DW value of 1.730 is greater than the limit (du) 1.6715 and less than $4-1.6715$ (2.3285), it can be concluded that there is no autocorrelation.

\section{Results of Multiple Correlation Analysis}

Multiple correlation is used to determine the relationship between two or more variables on the dependent variable simultaneously. The results of multiple correlation analysis in this study are as follows:

Table 6

\section{Results of Multiple Correlation Analysis}

\begin{tabular}{|c|c|c|c|c|}
\hline \multicolumn{5}{|c|}{ Model Summary } \\
\hline Model & $\mathrm{R}$ & $\begin{array}{c}\mathrm{R} \\
\text { Square }\end{array}$ & $\begin{array}{l}\text { Adjusted } \\
\text { R Square }\end{array}$ & $\begin{array}{l}\text { Std. Error of the } \\
\text { Estimate }\end{array}$ \\
\hline 1 &. $\mathbf{7 7 4 a}$ & .599 & .587 & \\
\hline
\end{tabular}

a. Predictors: (Constant), Tax Rate, Tax Socialization

Source: (Taken from the Appendix, 2019)

Table 6 shows the $\mathrm{R}$ value of 0.774 or $77.4 \%$, this shows that simultaneously the correlation between the tax socialization variable (X1) and the tax rate (X2) on the taxpayer compliance variable $(\mathrm{Y})$ is in a strong condition (1.60 - 0.799).

\section{Result of Determination Coefficient Analysis}

The coefficient of determination (Adjusted R Square) in essence measures how far the model's ability to explain the variation in the dependent variable. Table 6 shows the value of the Adjusted R Square coefficient of determination of 0.587 or $58.7 \%$. This shows that the 
taxpayer compliance variable (Y) which can be influenced by the tax socialization variable (X1) and the tax rate (X2) simultaneously is $58.7 \%$. While the rest of 0.413 or $41.3 \%$ is influenced by other variables that are not explained and discussed in this study.

\section{Results of Multiple Linear Regression Analysis}

To determine the effect of the independent variables, namely: tax socialization (X1) and tax rates $(\mathrm{X} 2)$ on the dependent variable, namely: taxpayer compliance (Y) restaurants in Sukabumi City can use multiple linear regression equations.

Table 7

\section{Results of Multiple Linear Regression Analysis}

\section{Coefficientsa}

\begin{tabular}{|c|c|c|c|c|c|c|}
\hline \multirow{2}{*}{\multicolumn{2}{|c|}{ Model }} & \multicolumn{2}{|c|}{$\begin{array}{l}\text { Unstandardized } \\
\text { Coefficients }\end{array}$} & \multirow{2}{*}{$\begin{array}{c}\text { Standardized } \\
\text { Coefficients } \\
\text { Beta }\end{array}$} & \multirow[b]{2}{*}{$\mathrm{t}$} & \multirow[b]{2}{*}{ Sig. } \\
\hline & & $\mathrm{B}$ & Std. Error & & & \\
\hline \multirow[t]{3}{*}{1} & (Constant) & 5,559 & 3,186 & & 1,745 & .086 \\
\hline & Tax Socialization & .921 & .169 & .538 & 5,465 & .000 \\
\hline & Tax rates & .614 & .191 & .316 & 3,216 & .002 \\
\hline
\end{tabular}

a. Dependent Variable: Taxpayer Compliance

Source: (Taken from the Appendix, 2019)

Based on the results obtained from the regression coefficient above, a regression equation can be made as follows:

$$
\begin{aligned}
& Y=a+b_{1} X 1+b_{2} X 2+e \\
& Y=5,559+0,921 X 1+0,614 X 2+e
\end{aligned}
$$

The constant (a) of 5,559 states that if there is no independent variable (Tax Socialization and Tax Rates) or the independent variable $=0$, then the amount of Restaurant Taxpayer Compliance is 5.559. The regression coefficient of Tax Socialization (X1) is 0.921, which means that if the value of Tax Socialization is increased by 1 time, it will increase Taxpayer Compliance by 0.921 times, assuming that the Tax Socialization variable has a fixed value. Meanwhile, the Tax Rate regression coefficient (X2) is 0.614 , which means that if the tax rate increases by 1 time, it will increase taxpayer compliance by 0.614 times, assuming the variable tax rate is fixed.

\section{T test (partial test)}

The $\mathrm{t}$ test in multiple linear regression is intended to test whether the parameters (regression coefficients and constants) that are assumed to estimate the equation / multiple linear regression model are the correct parameters or not. 


\section{The Effect of Tax Socialization (X1) on Taxpayer Compliance (Y)}

Based on table 7, partially shows the t-count of the tax socialization variable (X1) is 5.465 while the t-table with $\alpha=5 \%$ and $\mathrm{df}=(\mathrm{nk})$ is $\mathrm{df}=(70-2)=68$, then the t-table $(0,05 ; 68)=$ 1.66757 so that $\mathrm{t}$-count $>\mathrm{t}$-table $(5.465>1.66757)$, it can be concluded that the independent variable of tax socialization (X1) affects the dependent variable of taxpayer compliance (Y). Then the probability value sig. tax socialization $<0.05(0.00<0.05)$, it can be said that there is a significant effect of the tax socialization variable (X1) on the taxpayer compliance variable (Y). This means that statistically the tax socialization variable (X1) has a positive and partially significant effect on the taxpayer compliance variable (Y).

\section{The Effect of Tax Rates (X2) on Taxpayer Compliance (Y)}

Based on table 7 above, partially shows the t-count of the tax rate variable (X2) is 3,216 so that the $t$-count $>t$-table $(3,216>1,66757)$ can be concluded that the independent variable tax rate $(\mathrm{X} 2)$ has an effect on the dependent variable of compliance. taxpayer (Y). Then the probability value sig. tax rate $<0.02(0.02<0.05)$, it can be said that there is a significant effect of the tax rate variable (X2) on the taxpayer compliance variable (Y). This means that statistically the tax rate variable (X2) has a positive and partially significant effect on the taxpayer compliance variable $(\mathrm{Y})$.

\section{F Test (Simultaneous Test)}

The $\mathrm{F}$ test is used to determine whether the independent variables jointly affect the dependent variable or to find out whether the regression model can be used to predict the dependent variable or not.

\section{Table 8}

\section{F Test Result (Simultaneous Test)}

\begin{tabular}{|c|c|c|c|c|c|c|}
\hline \multicolumn{7}{|c|}{ ANOVAa } \\
\hline \multicolumn{2}{|c|}{ Model } & Sum of Squares & Df & Mean Square & $\mathrm{F}$ & Sig. \\
\hline 1 & Regression & 1488,044 & 2 & 744,022 & 50,035 & $.000 \mathrm{~b}$ \\
\hline & Residual & 996,298 & 67 & 14,870 & & \\
\hline & Total & 2484,343 & 69 & & & \\
\hline
\end{tabular}

a. Dependent Variable: Taxpayer Compliance

b. Predictors: (Constant), Tax Rate, Tax Socialization

Source: (Taken from the Appendix, 2019)

Based on table 8 , it is known that the calculated $\mathrm{F}$ value is 50.035 while the $\mathrm{F}$ table value is 3.98. Thus F count $>\mathrm{F}$ table (50.035> 3.98), it can be concluded that the independent variable tax socialization (X1) and tax rate (X2) together (simultaneously) have an influence on the 
dependent variable taxpayer compliance $(\mathrm{Y})$. Then it can be seen from the probability value from the table which is equal to 0.00 which is smaller than the significance level of $0.05(0.00$ $<0.05)$, this means that the tax socialization variables (X1) and the tax rate $(\mathrm{X} 2)$ are together (simultaneously). has a significant effect on taxpayer compliance (Y).

\section{CONCLUSIONS AND SUGGESTIONS}

\section{Conclusion}

Based on the data and results obtained and the tests that have been carried out on the problem, the following conclusions can be drawn:

1. The tax socialization assessment produces an average value of $\mathrm{X} 1.1=3.79, \mathrm{X} 1.2=4.23$, $\mathrm{X} 1.3=4.19, \mathrm{X} 1.4=3.56, \mathrm{X} 1.5=3.13$, and X1 .6 = 4.74, for an overall mean of 3.94 . Respondents' responses show that on average the overall response agrees with the tax socialization conducted on restaurants in Sukabumi City.

2. The tax rate assessment produces an average value of $\mathrm{X} 2.1=4.43, \mathrm{X} 2.2=3.79, \mathrm{X} 2.3=$ $2.80, \mathrm{X} 2.4=3.73$, with a total average overall of 3,68 . Respondents' responses indicate that on average the overall response is neutral with the imposition of tax rates on restaurants in Sukabumi City.

3. Assessment of taxpayer compliance produces an average value of $\mathrm{Y} 1=4.07, \mathrm{Y} 2=4.17, \mathrm{Y} 3$ $=4.76, \mathrm{Y} 4=3.00, \mathrm{Y} 5=3.63, \mathrm{Y} 6=3.70, \mathrm{Y} 7=4.54, \mathrm{Y} 8=4.20$, and $\mathrm{Y} 9=4.30$, for an overall mean of 4.04. Respondents' responses indicate that on average overall they agree on the compliance of restaurant taxpayers in Sukabumi City, in the sense that respondents are obedient to the presence of taxpayers for their respective restaurants.

4. The partial test results show t-count $>\mathrm{t}$-table $(5.465>1.66757)$ with a probability value of sig. tax socialization $<0.05(0.00<0.05)$. This means that tax socialization has a positive and significant effect on restaurant taxpayer compliance in Sukabumi City.

5. The partial test results show t-count $>$ t-table $(3,216>1,66757)$ with a probability value of sig. tax rate $<0.05(0.02<0.05)$. This means that tax rates have a positive and significant effect on restaurant taxpayer compliance in Sukabumi City.

6. The test results simultaneously show F count $>\mathrm{F}$ table (50.035> 3.98) with a probability value of sig. socialization of taxes and tax rates $<0.05(0.00<0.05)$. This means that the socialization of taxes and tax rates together (simultaneously) has a positive and significant effect on restaurant taxpayer compliance in Sukabumi City. 


\section{Suggestion}

Even though researchers have compiled the research as well as possible, there are still many deficiencies in this study with all its limitations. The following are various suggestions put forward by researchers based on the research results:

1. For Restaurant Taxpayers; It is hoped that they will participate more in the state by becoming taxpayers who are obedient to tax regulations. because with the increase in taxpayer compliance, the welfare of citizens will also increase.

2. For the Government (Directorate General of Taxes); We recommend that you do a lot of policy considerations related to the determination of the rate that will be applied to taxpayers. With rates that are considered burdensome to taxpayers, how high the socialization and understanding of taxpayers will not affect taxpayer compliance in paying taxes, on the other hand, if the rates are still affordable or not burdensome to taxpayers, taxpayers will happily carry out their tax obligations.

3. For further researchers; It is hoped that the next research will not be limited to the socialization of taxes and tax rates but also to add other variables that play a role in taxpayer compliance in future studies. As well as subsequent research can carry out similar research by replacing more specific research objects

\section{ACKNOWLEDGEMENT}

Praise and gratitude for Allah SWT who has given His grace and gifts. And I thank all those who have provided support that the author cannot mention one by one. The author fully realizes that this article is still far from perfect, because of this limitation, with all humility the writer is willing to accept suggestions and criticism from all parties.

\section{REFERENCE}

[1] A. Julianto, "Pengaruh Tarif, Sosialisasi serta Pemahaman Perpajakan Terhadap Kepatuhan Wajib Pajak UMKM di Kota Semarang,” J. Undinus, vol. 6, 2016.

[2] Mardiasmo, Perpajakan Edisi Revisi Tahun 2018. 2018.

[3] J. R. Ritcher, “An Econometrics Analysis Of Income Tax Evasion And It's Detection,” RAND J. Econ., vol. 22, no. 1, pp. 14-35, 1987.

[4] S. Soekanto, Kamus sosiologi. PT RajaGrafindo Persada, 1993.

[5] B. Sormin and S. Rahim, “Analisis Penerapan Pajak Penghasilan Usaha Mikro Kecil dan Menengah (Pada KPP Pratama Makassar Selatan dan Makassar Utara),” Bongaya J. Res. 
Account., 2019.

[6] R. Sudirman and A. Amiruddin, Perpajakan Pendekatan Teori dan Praktek. 2012.

[7] R. Soemitro, Dasar-dasar Hukum Pajak dan Pajak Pendapatan. 1977.

[8] Mir'atusholihah, S. Kumadji, and B. Ismono, "Pengaruh Pengetahuan Perpajakan, Kualitas Pelayanan Fiskus, dan Tarif Pajak Terhadap Kepatuhan Wajib Pajak," $J$. Perpajak., 2015.

[9] S. Nurmantu, Pengantar perpajakan. Yayasan Obor Indonesia, 2005.

[10] G. D. of Tax, Category of Taxpayers. 2015.

[11] Sugiyono, Metode Penelitian Kuantitatif, Kualitatif dan R\&D. Bandung, 2018.

[12] S. C. R. F. M. Agency, "Restaurant Data Registered with the Taxpayer for 2017-2019," 2019.

[13] I. Ghozali, Aplikasi Analisis Multivariate dengan Program IBM SPSS 23. 2016.

[14] Ansofino, Jolianis, Yolamalinda, and H. Arfilindo, "Buku Ajar Ekonometrika," Ilmu Ekonomi. 2016. 